Marta Gołuch

\title{
Kontrola abuzywności postanowień umów bankowych dotyczących ubezpieczenia niskiego wkładu własnego. Glosa aprobująca do wyroku Sądu Okręgowego w Warszawie z 27.10.2016 r. (XXVII C 3361/16; niepubl.)
}

\begin{abstract}
Glosa odnosi się do wyroku Sądu Okręgowego w Warszawie z 27.10.2016 r. (XXVII C 3361/16) dotyczącego uznania postanowień umownych związanych z ubezpieczeniem niskiego wkładu własnego za klauzule abuzywne. W związku z coraz częstszym stosowaniem przez banki w umowach kredytowych dodatkowego zabezpieczenia, jakim jest ubezpieczenie niskiego wkładu własnego powstała konieczność rozważenia czy nie stanowi ono świadczenia nienależnego, o którym mowa w art. $410 \S 2$ kodeksu cywilnego wskutek uznania odpowiednich postanowień umowy kredytowej za klauzulę abuzywną. Stosowanie przez banki klauzul abuzywnych w wykorzystywanych przez nie wzorcach umownych przysparzało korzyści majątkowej poprzez obciążenie konsumentów kosztami zawarcia przez banki z ubezpieczycielem generalnej umowy ubezpieczenia niskiego wkładu w kredytach i pożyczkach hipotecznych, co bezpośrednio skutkowało wzbogaceniem banków o pobierane od konsumentów kwoty z tytułu kosztów przedmiotowego ubezpieczenia niskiego wkładu.
\end{abstract}

1. Glosowane orzeczenie zostało wydane w następstwie procesu kontroli instancyjnej wyroku Sądu Rejonowego dla Warszawy Śródmieścia w Warszawie z 8.6.2016 r., sygn. akt I C 147/16. Wyrok Sądu Rejonowego zapadł w następującym stanie faktycznym. Powoda łączyła $\mathrm{z}$ pozwanym bankiem umowa $\mathrm{z}$ dnia 8.5.2006 r. o kredyt hipoteczny dla osób fizycznych „mPlan" waloryzowany kursem CHF na kwotę 158.262,00 zł na okres 360 miesięcy. Według powoda $\mathrm{w}$ czasie trwania umowy zostały pobrane od niego nienależnie składki z tytułu ubezpieczenia niskiego wkładu w dniach: 24.5.2006 r., (1 387,83 zł), 3.6.2009 r. (1 248,48 zł), 31.5.2012 r. (958,24 zł), a § 3 ust. 4 wiążącej strony umowy, na podstawie którego pobrano składki stanowił niedozwolone postanowienie umowne. W ocenie Sądu I instancji sposób zabezpieczenia kredytu w postaci ubezpieczenia niskiego wkładu został powodowi narzucony, a sporna klauzula ze względu na swoją zdawkowość powodowała dezorientację konsumenta co do jego praw i obowiązków. Zdaniem Sądu 
Rejonowego takie sformułowanie wzorca umowy należało uznać za sprzeczne z dobrymi obyczajami, gdyż zmierzało do dezinformacji, dezorientacji, wywołania błędnego przekonania konsumenta oraz wykorzystania jego niewiedzy lub naiwności. Jednocześnie Sąd I instancji nie wykluczył możliwości pobierania przez bank dodatkowej opłaty czy prowizji lub zwiększonego oprocentowania od kwoty udzielonego kredytu, która powinna stanowić wymagany wkład własny, jednak wskazał, że opłata ta powinna być proporcjonalna do kosztów ponoszonych w tym przypadku przez bank, nie zaś pokrywać z nawiązką nawet potencjalne koszty. W konsekwencji uznano kwestionowane postanowienie umowne za niedozwoloną klauzulę umowną i stwierdzono, że nie wiąże ona powoda, przy jednoczesnym jego związaniu pozostałymi postanowieniami umownymi. Stwierdzenie to skutkowało nałożeniem przez Sąd na pozwany bank obowiązku zwrotu nienależnie uzyskanych sum pieniężnych.

Sąd Okręgowy w ramach kontroli instancyjnej orzeczenia Sądu Rejonowego, na skutek apelacji strony pozwanej zarzucającej naruszenie art. $385^{1} \S 1$ kodeksu cywilnego ${ }^{1}$ (dalej: kodeks cywilny/k.c.) i art. $385^{2}$ k.c. oraz art. 221 k.c., zaaprobował przedstawiony przez Sąd I instancji pogląd prawny i w glosowanym orzeczeniu skonstatował, iż Sąd Rejonowy trafnie ocenił występowanie przesłanek abuzywności z art. $385^{1} \S 1$ k.c. Stanowisko Sądu Okręgowego w Warszawie stanowi rozstrzygnięcie istotnego zagadnienia prawnego, dotyczącego bezpodstawnego wzbogacenia się baku wskutek nienależnego obciążenia powoda kosztami zawarcia przez siebie z ubezpieczycielem generalnej umowy ubezpieczenia niskiego wkładu w kredytach i pożyczkach hipotecznych. Kwestia ta była przedmiotem burzliwej dyskusji przedstawicieli doktryny prawniczej na kanwie abuzywności postanowień zawartych we wzorcach umów stosowanych przez banki.

2. Należy w pełni podzielić stanowisko Sądu Okręgowego dotyczące uznania pobranych przez pozwanego składek $\mathrm{z}$ tytułu ubezpieczenia niskiego wkładu własnego za świadczenie nienależne, o którym mowa w art. 410 § 2 k.c. wskutek uznania postanowienia § 3 ust. 4 umowy kredytowej za klauzulę abuzywną z uwagi na upadek podstawy do pobrania składek. Abuzywne postanowienie umowne nie wiązało konsumenta, a tym samym spełniły się przesłanki uzasadniające dokonanie zwrotu przez bank nienależnie uzyskanej kwoty. Strona pozwana uzyskała korzyść majątkową poprzez obciążenie powoda kosztami zawarcia przez siebie z ubezpieczycielem generalnej umowy ubezpieczenia niskiego

\footnotetext{
${ }^{1}$ Ustawa z 23.4.1964 r. Kodeks cywilny (t.j. Dz.U. z 2017 r. poz. 459, ze zm.).
} 
wkładu w kredytach i pożyczkach hipotecznych i wzbogaciła się o pobrane od powoda kwoty z tytułu kosztów ubezpieczenia niskiego wkładu. W zakresie tych kosztów, świadczenie spełnione przez powoda na rzecz pozwanego banku stanowiło zatem świadczenie nienależne w rozumieniu art. $410 \S 2$ k.c. Należy również wskazać, że same przesłanki bezpodstawnego wzbogacenia przy świadczeniu nienależnym należy rozumieć specyficznie, bowiem już samo spełnienie świadczenia powoduje zubożenie po stronie spełniającego, a jego przyjęcie stanowi wzbogacenie po stronie przyjmującego ${ }^{2}$.

Artykuł $385^{1}$ k.c. jest implementacją art. 3 dyrektywy Rady 93/13/EWG z 5.4.1993 r. $\mathrm{w}$ sprawie nieuczciwych warunków w umowach konsumenckich ${ }^{3}$. Jego stosowanie uzależnione jest od wystąpienia dwóch przesłanek: sprzeczności z dobrymi obyczajami oraz rażącego naruszenia interesów konsumenta, przy czym przesłanki te muszą być spełnione łącznie ${ }^{4}$. W orzecznictwie spotykany jest pogląd, zgodnie z którym nie zawsze klauzule, które są sprzeczne $\mathrm{z}$ dobrymi obyczajami, będą jednocześnie rażąco naruszać interesy konsumentów ${ }^{5}$.

W glosowanym orzeczeniu Sąd Okręgowy sprecyzował, iż interpretacji pojęcia dobrych obyczajów należy dokonywać w oparciu o normy pozaprawne, jak normy moralne i zwyczajowe stosowane w działalności gospodarczej, a także zasady etyczne stosowane we wszystkich rodzajach działalności ze szczególnym uwzględnieniem zasady lojalności.

Stosownie do dyrektywy 93/13/EWG, dokonując oceny postanowienia umownego pod kątem jego sprzeczności z dobrymi obyczajami istotne jest, czy przedsiębiorca traktujący konsumenta W sposób sprawiedliwy i słuszny mógłby racjonalnie spodziewać się, iż konsument zgodziłby się na sporne postanowienie wzorca w drodze negocjacji indywidualnych ${ }^{6}$.

W uzasadnieniu wyroku z 27.10.2016 r. w sprawie XXVII C 3361/16 Sąd Okręgowy wyraźnie nawiązał do wcześniejszego orzeczenia tego Sądu w sprawie XXVII Ca 2077/16, w którym zawarto bardzo podobną tezę, a mianowicie, że brak rzetelnej informacji co do funkcji, mechanizmu działania, alternatywnych metod zabezpieczenia stanowił działanie sprzeczne z dobrymi obyczajami ze strony banku i rażąco naruszał interesy konsumenta, który dysponując (ewentualnie) innymi sposobami zabezpieczenia, pozostawał

\footnotetext{
${ }^{2}$ Wyrok SA w Krakowie z 18.12.2014 r., I ACa 1280/14.

${ }^{3}$ Dz.Urz. WE 1993 Nr L 95/29 ze zm.

${ }^{4}$ E. Łętowska, Ochrona niektórych praw konsumentów. Komentarz, Warszawa 2001, art. 385 ${ }^{1}$, Nb 68, s. 104.

${ }^{5}$ Wyrok SN z 13.10.2010 r., I CSK 694/09.

${ }^{6}$ Wyrok TSUE z 14.3.2013 r. w sprawie C-415/11, Mohamed Aziz v. Caixa d'Estalvis de Catalunya, Tarragona i Manresa (Catalunyacaixa).
} 
przy ubezpieczeniu niskiego wkładu własnego, które było najbardziej korzystne z punktu widzenia banku ${ }^{7}$.

Zgodnie ze stanowiskiem Sądu Najwyższego „działanie wbrew dobrym obyczajom” w zakresie kształtowania treści stosunku obligacyjnego wyraża się w tworzeniu przez partnera konsumenta takich klauzul umownych, które godzą w równowagę kontraktową tego stosunku $^{8}$. Sąd Najwyższy wyraził także pogląd, iż art. $385^{1} \S 1$ zd. 1 k.c. jest odpowiednikiem art. 3 ust. 1 dyrektywy nr 93/13/WE, stanowiącym, że klauzulę umowną, która nie została uzgodniona indywidualnie, należy uznać za niedozwoloną, jeżeli naruszając zasadę dobrej wiary, powoduje istotną i nieusprawiedliwioną dysproporcję praw i obowiązków kontraktowych na niekorzyść konsumenta 9 .

Za słuszne należy uznać także wyrażone przez Sąd Okręgowy w głosowanym orzeczeniu stanowisko, iż ubezpieczenie niskiego wkładu własnego stanowi jeden ze sposobów zabezpieczeń spłaty kredytu, a zatem jest świadczeniem o charakterze ubocznym.

3. Stan faktyczny zakreślony $w$ glosowanym orzeczeniu jest także doskonałym źródłem rozważań nad kwestią indywidualnego uzgodnienia $\mathrm{z}$ konsumentem treści postanowień zawartych $\mathrm{W}$ proponowanych przez banki wzorcach umownych. Zgodnie $\mathrm{z}$ art. $385^{1} \S 3$ k.c. nie są indywidualnie uzgodnione te postanowienia, które zostały przejęte z wzorca zaproponowanego przez kontrahenta. Jak trafnie wskazał Sąd Okręgowy, treść wskazanego powyżej przepisu w połączeniu $\mathrm{z}$ art. $385^{1} \S 4$ k.c. kreuje domniemanie braku indywidualnego uzgodnienia. W sprawie XXVII C 3361/16 strona pozwana podniosła, że zabezpieczenie spłaty kredytu poprzez ubezpieczenie niskiego wkładu własnego było konsekwencją świadomej decyzji powoda odnośnie kredytowania zakupu nieruchomości bez angażowania środków własnych.

Jakże słusznym okazało się w tej kwestii spostrzeżenie Sądu Rejonowego, podkreślone także przez Sąd Okręgowy, iż powód zapoznał się ze spornym postanowieniem umownym dopiero na etapie podpisywania umowy kredytowej, natomiast w samym wniosku kredytowym (sporządzonym na standardowym formularzu bankowym) brak było informacji o wymaganym wkładzie własnym. W części dotyczącej zabezpieczeń widniało jedynie enigmatyczne sformułowanie o zabezpieczeniu przejściowym

\footnotetext{
${ }^{7}$ Wyrok SO w Warszawie z 6.9.2016 r., XXVII Ca 2077/16.

${ }^{8}$ Wyrok SN z 13.7.2005 r., sygn. akt I CK 832/04.

${ }^{9}$ Wyrok SN z 3.2.2006 r., sygn. akt I CK 297/05.
} 
w postaci ubezpieczenia kredytu, które jednak nie wskazywało kto ma być beneficjentem tego ubezpieczenia ani też jakie mają być jego warunki ${ }^{10}$. Zważywszy na powyższe, nie sposób nie zgodzić się z ustaleniem Sądu Okręgowego, że powód nie miał wpływu na ustalenie treści postanowienia umownego zaczerpniętego z wzorca stworzonego przez bank na długo przed zawarciem z nim umowy. Wskazuje się, że konsument nie ma rzeczywistego wpływu na treść danego postanowienia, jeśli przedsiębiorca przedstawił mu kilka wariantów brzmienia danej klauzuli umownej, spośród których konsument miałby wybrać jedną ${ }^{11}$.

W omawianym orzeczeniu z 27.10.2016 r. Sąd Okręgowy w Warszawie przyjąt, że oceniane postanowienie umowne kształtowało obowiązki powoda w sposób niezgodny $\mathrm{z}$ zasadą równorzędności stron, a konsument $\mathrm{w}$ chwili podpisania umowy nie miał możliwości ocenić jego ekonomicznych skutków. Konsument ponosił cały ciężar ekonomiczny zawarcia umowy ubezpieczenia, choć kontrahent nie przedstawił mu ani warunków opłacanej ochrony ubezpieczeniowej, ani skutków wypłaty świadczenia $\mathrm{z}$ ubezpieczenia dla kredytobiorcy. Zabezpieczenie spłaty kredytu we wskazanej części było de facto zabezpieczeniem interesu wyłącznie banku, przy jednoczesnym braku zabezpieczenia kredytobiorcy, pomimo ponoszenia przez niego kosztów przedmiotowego ubezpieczenia. Poniesienie całości kosztów ubezpieczenia niskiego wkładu przez konsumenta stawiała go w oczywiście niekorzystnej sytuacji, więc nie mogło być wątpliwości, co do rażącego charakteru naruszenia jego interesów, jak również co do jego sprzeczności z dobrymi obyczajami. ${ }^{12}$

W wyroku z 3.2.2016 r. Sąd Apelacyjny w Warszawie zaznaczał, że interes konsumenta to nie tylko interes w wymiarze ekonomicznym, ale również niewygoda organizacyjna, strata czasu czy nierzetelne traktowanie ${ }^{13}$.

Ocena czy doszło do naruszenia interesu konsumenta dokonuje się przez pryzmat ustalenia, jak wyglądałyby prawa i obowiązki stron bez zakwestionowanej klauzuli ${ }^{14}$.

4. Reasumując, w głosowanym orzeczeniu Sąd Okręgowy nie kwestionował tego, że zgodnie $\mathrm{z}$ art. 93 ust. 1 ustawy Prawo bankowe w celu zabezpieczenia wierzytelności, które wynikają z czynności bankowych, bank może żądać zabezpieczenia przewidzianego w kodeksie cywilnym i prawie wekslowym oraz zwyczajami przyjętymi w obrocie krajowym i zagranicznym, jednak wskazywał, że sposób zabezpieczenia musi być zgodny

\footnotetext{
${ }^{10}$ Wyrok SO w Warszawie z 27.10.2016 r, XXVII C 3361/16.

${ }^{11}$ M. Bednarek, System Prawa Prywatnego, t. 5, 2013, s. 763.

${ }^{12}$ Wyrok SO w Warszawie z 27.10.2016 r, XXVII C 3361/16.

${ }^{13}$ Wyrok SA w Warszawie z 3.2.2016 r., VI Ca 12/15.

${ }^{14}$ Wyrok SN z 27.11.2015 r., I CSK 945/14.
} 
z obowiązującymi przepisami, w szczególności z regulacją dotyczącą ochrony konsumentów oraz klauzul niedozwolonych. Precyzując, „Sąd Okręgowy nie kwestionuje samej dopuszczalności i skuteczności korzystania z ubezpieczenia niskiego wkładu jako formy zabezpieczenia spełnienia części świadczenia z umowy kredytu, ale uznał za abuzywne, co do treści, te postanowienia umowy, według których koszt zabezpieczenia ponosi w całości konsument nie uzyskując w zamian żadnych korzyści" ${ }^{15}$.

W konkluzji przytoczonych rozważań Sąd Okręgowy uznał, że Sąd Rejonowy zasadnie ocenił, iż uiszczenie przez powoda na rzecz pozwanego kwoty 3.594,55 zł stanowiło świadczenie nienależne stosownie do art. 410 § 2 k.c. albowiem wskutek uznania postanowienia § 3 ust. 4 umowy kredytowej za klauzulę abuzywną doszło do upadku podstawy do pobrania składek tytułem ubezpieczenia niskiego wkładu zgodnie $\mathrm{z}$ art. $385^{1} \S 1$ k.c. (postanowienie nie wiązało konsumenta), a tym samym spełniły się przesłanki uzasadniające dokonanie zwrotu przez bank nienależnie uzyskanej kwoty.

Mając powyższe na uwadze, poczynioną przez Sąd Okręgowy w Warszawie w głosowanym wyroku z 27.10.2016 r., XXVII C 3361/16 konstatację uznać należy za zasługującą na pełną aprobatę.

\footnotetext{
${ }^{15}$ Wyrok SO w Warszawie z 27.10.2016 r., XXVII C 3361/16.
} 


\section{Summary.}

The Gloss refers to the verdict of the District Court in Warsaw of 27.10.2016 (XXVII C 3361/16) concerning the recognition of contractual clauses related to insurance of low selfcontribution for abusive clauses. Due to the increasing use of additional collateral by banks in credit agreements, which is low self-contribution, it is necessary to consider whether or not it constitutes an undue benefit referred to in art. $410 \S 2$ Civil Code as a result of the recognition of the relevant provisions of the credit agreement as an abusive clause. The use of abusive clauses by banks in which they use contract templates brought them financial benefits. Banks charged consumers with the cost of concluding a general insurance contract for low contributions to mortgage loans and mortgages. This has resulted in the direct enrichment of banks by consumers charged with the costs of the insured low contribution insurance.

\section{Marta Gołuch}

Absolwentka Wydziału Prawa i Administracji Uniwersytetu Kardynała Stefana Wyszyńskiego w Warszawie na kierunku prawo. Ukończyła studia podyplomowe z zakresu prawa dowodowego. Obecnie uczestniczka studiów doktoranckich na kierunku prawo na WPiA UKSW. Od 2013 r. zatrudniona jako asystent sędziego w sądach powszechnych, w tym w Sądzie Okręgowym w Warszawie i Sądzie Apelacyjnym w Warszawie. 